\title{
VIII
}

\section{THE ARSENO-THERAPY OF SYPHILIS; STOVARSOL, AND TRYPARSAMIDE}

\author{
By E. T. BURKE, D.S.O., M.B., Сн.B.
}

IN a previous number of this Journal reference was made to the use of arsenobenzol in the prophylaxis of syphilis, and it was mentioned that investigations had been carried out by Levaditi and his colleagues with the acetyl derivative of oxyaminophenyl arsinic acid, " I9o," or Stovarsol. It is the purpose of this paper, in a " bird'seye view" of the arseno-therapeutic field, to direct attention to that work, and to attempt to assess its value.

The Future is always to be found slumbering in the lap of History; and it therefore becomes necessary, for a clear comprehension of the matter, to consider briefly some of the representative arsenical compounds which have been used in the treatment of syphilis.

Although from the time of Fallopius (I523-62) arsenic has been used as an antiluetic remedy, it was, until about the beginning of the present century, only in its inorganic form. The organic and the inorganic arsenical compounds may be classified according as to whether the element exerts its atomicity as a triad or as a pentad. Upon the valency of the arsenic depends to a great degree the therapeutic value of the compound, especially if it is an organic one.

Inorganic Arsenical Salts.-The use of arsenic in syphilis was probably suggested in the first instance by the experience of it in other conditions-not syphiliticbut resembling in some degree some of the many manifestations of that disease. Its tonic properties, its value in anæmia, and its beneficial effects in many skin disorders, were all well known before the bold mariners of Columbus returned from Hayti. The ordinary white arsenicacidum arseniosum - was found to have a distinct use in intractable cases of syphilis which did not respond favourably to mercury. Upon the introduction of hypodermic medication, the drug was given in the form of subcutaneous injections of the solutions of Fowler and 


\section{BRITISH JOURNAL OF VENEREAL DISEASES}

of Donovan. All solutions of inorganic arsenical salts were found, however, to suffer from two great disadvantages: (I) they caused much tissue irritation; and (2) they possessed no well-marked superiority over mercury.

A contribution to the treatment of syphilis which is now almost forgotten was made by Herzfeld in I9Io. $\mathrm{He}$ reported two cases which had resisted mercury for six months and for five years respectively. To these he gave arsenic by the hypodermic method. The injections were prepared by adding to Ioo c.c. of distilled water I gramme of arsenious acid, and $2 \cdot 25$ c.c. of normal soda. This was boiled till the solution was clear. It was then filtered and made up to Ioo grammes with distilled water. The initial dose was 0.25 c.c., and this was gradually increased to 2 c.c. The first case was cured after fourteen injections, and the second after twenty-four. This was the last shot fired against syphilis by the inorganic arsenical batteries before the heavy artillery of the organic compounds picked up the range.

In syphilis there occurs a certain degree of hæmolysis. Arsenic exerts upon erythrocytes a protective action against certain hæmolysins, particularly those of protozoal diseases, such as malaria and trypanosomiasis. Whether or not it be accepted that Treponema pallidum is a protozöon, this at least is established : that arsenic is more active against the protozoa than against the bacteria ; that its power is more marked when it is organically combined ; and that this is especially so when the element is exerting its trivalent function.

Organic Arsenical Compounds.-In these, arsenic is in direct chemical combination with a carbon atom; and it would seem to be this which is responsible for the small degree of toxicity exhibited by these compounds when compared with the inorganic salts. In this group the trivalent preparations are more potent therapeutically and less toxic somatically than are the pentavalents.

The organic arsenicals are divided into two series: (I) the aliphatic, or fatty series; and (2) the aromatic, or benzene ring series. With the former we are not specially concerned. They comprise the cacodylates, being derived from arsenium dimethyl or cacodyle. It is the benzene ring series which has figured so prominently in the therapeutics of syphilis. 


\section{ARSENO-THERAPY OF SYPHILIS}

Since 1907 a great many of these aromatic arsenicals have been used and suggested as antiluetic agents. The exigencies of space will only permit of a short reference to the more important links in the evolutionary chain.

The starting point of modern arseno-therapy may be taken as the discovery of sodium para-aminophenyl arsenate-sodium arsanilate. This body was first prepared in 1863 by Bechamp, a French chemist. It entered the field of therapeutics through the Teutonic gate under the name of atoxyl. It is the sodium salt of para-aminophenyl arsinic acid-arsanilic acid.

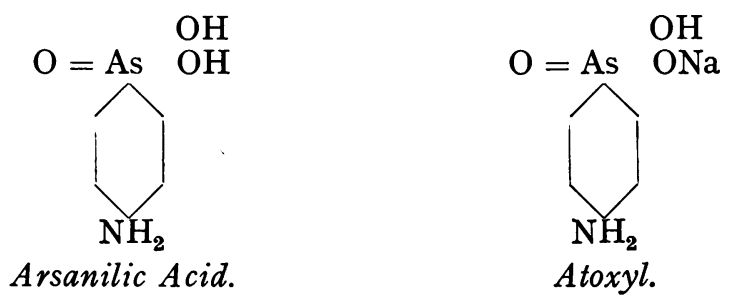

The arsenic is pentavalent and is directly attached to the benzene ring, the amino group being in the para position. The arsenic content of atoxyl is 24.09 per cent. Upon adding an acetyl group to atoxyl the result is sodium acetyl para-aminophenyl arsenate or arsacetin:

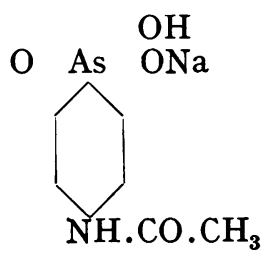

The arsenic is again pentavalent, but the acetyl group renders the compound both more stable and less toxic than atoxyl.

The pentavalent arsenicals have the disadvantage that, as a rule, the $\mathrm{C} / \mathrm{T}$ co-efficient is a very narrow one. This co-efficient expresses the relationship between the curative dose $(\mathrm{C})$ and the toxic dose $(\mathrm{T})-\mathrm{C}$ being always expressed as unity. The efficiency of these compounds varies indirectly with the size of the fraction. The pentavalents are comparatively non-toxic until the arsenic is liberated. In the body this occurs very slowly, so that at first but little more than the ordinary elemental effect is produced. In time, however, the arsenic accumulates and poisoning 


\section{BRITISH JOURNAL OF VENEREAL DISEASES}

occurs. These compounds are very rapidly excreted, and they pass out of the body practically unchanged. The net result is, that in order to produce any real therapeutic effect, large doses must be given, and, owing to the rapidity of excretion, the kidney and liver cells become damaged. According to Rohl and Friedberger, the greater part of the therapeutic efficiency of organic pentavalent arsenic is due to its being transformed in the body, into the trivalent form, just as arsenic pentoxide is partly reduced to arsenious acid. It would seem that trivalent arsenic, administered into the body tissues or blood, provides a better stimulus for the production of the arseno-protein lethal to treponemata than does pentavalent arsenic. It is the elemental arsenic which is apparently essential, and a trivalent compound is, so to speak, " more broken down" than a pentavalent one.

It will be convenient here to consider these trivalents before returning to the latest pentavalent compounds. To the trivalent group belong the arsenobenzols.

The outstanding representative is salvarsan, or " 606 ," which was introduced by Ehrlich in IgIo. The " mothersubstance" is a double-ring compound with the formula :

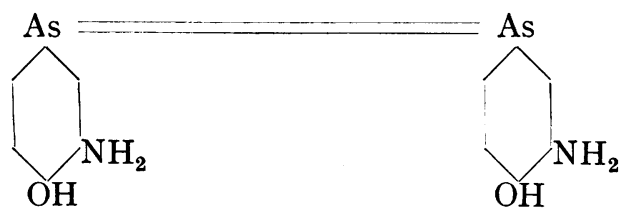

Dioxy-diamino-arsenobenzol.

This substance is insoluble in water. It is not, therefore, sold in this form, but as the hydrochloride :

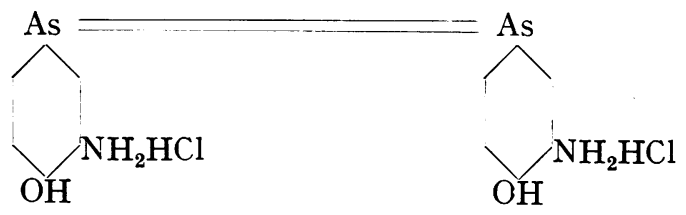

Dioxy-diamino-arsenobenzol dihydrochloride.

Salvarsan.

This is slightly soluble in water, but the solution is so strongly acid in reaction as to be quite unsuitable for intravenous or intramuscular injection. To prepare this compound for administration sodium hydroxide is added. A precipitate is formed which, however, redissolves in 


\section{ARSENO-THERAPY OF SYPHILIS}

excess of the alkali. A solution of a sodium salt is thus produced, and it is this which is meant when one speaks of " an injection of salvarsan." It is represented by the formula :

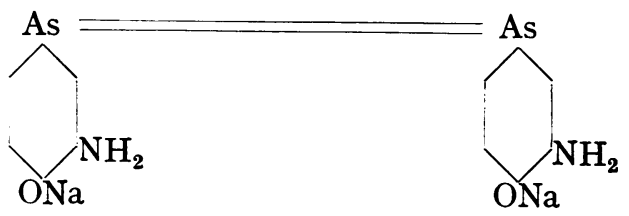

Sodium dioxy-diamino-arsenobenzol.

This compound undergoes a series of changes in the blood and tissues, at one stage of which, according to Siebing, the pentavalent oxyaminophenyl arsinic acid is formed. However that may be, there seems but little doubt that at some stage of the intracorporeal transformation of arsenical compounds some of the element is in a combination which permits of it giving rise to the treponemicidal arseno-protein. The valency of the arsenic in the compound as administered is apparently an important factor in deciding the rapidity and efficiency with which this is formed. It is a little difficult to understand why trivalent arsenic-as salvarsan-should be so efficient if it is transformed in the body into a pentavalent compound, since if pentavalent arsenic is administered the therapeutic results are not as good. It is possible that when arsenic is given in the pentavalent form, it may act in a very different way from what it does when it is actually formed by the body from the trivalent. The route of administration must also be another factor. The influence upon the compound, of blood, of muscle-extract, and of gastric juice, must in each case be entirely different. As will be seen presently, the ingestion of pentavalent arsenic in the form of acetyloxyaminophenyl arsinic acid does produce excellent results ; but what metamorphosis it undergoes before it exerts its remarkable abortive effect upon syphilis is not clear.

The experiments of Levaditi upon atoxyl elucidated the fact that the lethal action of this drug against trypanosomes depends upon it being transformed in the body into a substance which he termed trypanotoxyl. This is an arsenicated toxalbumin elaborated by the tissues from atoxyl. In view of the fact that more recently, in connection with bismuth, the similar derivative has been named 


\section{BRITISH JOURNAL OF VENEREAL DISEASES}

by Levaditi bismoxyl, it would appear to be more desirable to refer to these toxalbumins by the name of the element which gives rise to them, e.g., bismoxyl, arsenoxyl, stiboxyl, etc., rather than by the name of the organism which they may happen to destroy. From Levaditi's work it is clear that the essence of the therapeutic power of any compound formed from the elements of the fifth group of the Mendelieff series lies in the fact that the element is capable of being activated by tissue-extracts. The variations of that power, and the different degrees of toxicity depend-among other possible factors-upon the chemical structure of the compound, the route of administration, and the species of organism against which it is employed.

The work of Ehrlich upon atoxyl and oxyaminophenyl arsinic acid was the starting point of Fourneau's investigations. He found that German-manufactured specimens of these substances contained many impurities-principally sodium arsenite-and that they were in consequence more toxic than their chemical structure warranted. $\mathrm{He}$ came to the conclusion that the majority of untoward effects attributed to atoxyl were really due to these impurities. When Fourneau investigated pure oxyaminophenyl arsinic acid and its sodium salt, prepared by Madinaveitia, Trefouel, and Puyal, he found this view to be correct. The sodium salt, however, quickly became oxidised on exposure to the air, and in solution its toxicity increased in direct ratio with its age. Oxyaminophenyl arsinic acid, or " I89," and its sodium salt, are represented by the following formulæ :
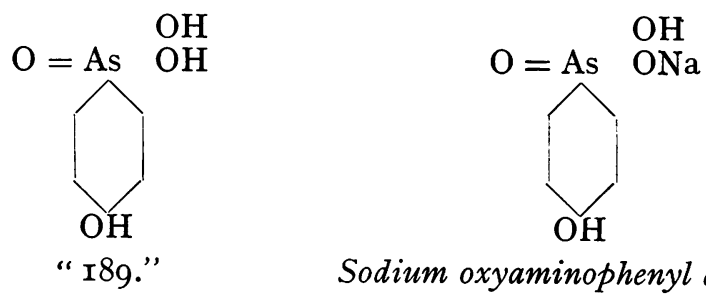

Sodium oxyaminophenyl arsenate.

The arsenic is here again pentavalent. These formulæ should be compared with those of arsanilic acid and of atoxyl. The sodium salt of " I89 " has an arsenic content of 26.5 per cent. With this salt Navarro-Martin experimented on trypanosomiasis. Levaditi and NavarroMartin investigated its effect upon the spirillosis of fowls 


\section{ARSENO-THERAPY OF SYPHILIS}

and upon experimental syphilis in the rabbit. A comparison between the sodium salt of " I89," atoxyl, and arsenophenylglycine-in the last of which the arsenic is trivalent-administered subcutaneously, gave the following results :

$\begin{array}{llll}\text { Sodium salt of " } \mathrm{I} 89 " & . & . & \mathrm{C} / \mathrm{T}=\mathrm{I} / 5 \\ \text { Arsenophenylglycine } & \cdot & \cdot & \cdot \mathrm{C} / \mathrm{T}=\mathrm{I} / 3 \\ \text { Atoxyl } & \cdot & \cdot & \cdot \mathrm{C} / \mathrm{T}=\mathrm{I} / 2\end{array}$

These were the co-efficients obtained in the trypanosomiasis of mice. An interesting fact brought to light was that trypanosomes did not develop arseno-resistance to sodium oxyaminophenyl arsenate. For the spirillosis of fowls the C/T of the sodium salt of "I89" was found to be $\mathrm{I} / 8$; in rabbit syphilis it was $\mathrm{I} / 4$. Pierret rightly emphasises the danger of taking the $\mathrm{C} / \mathrm{T}$ co-efficient of a drug upon chicken spirillosis as being indicative of its value in the treatment of human syphilis. The results of a large number of experiments by Navarro-Martin and Stephanopoulo, and by Fourneau and Navarro-Martin in collaboration with M. and Mme. Trefouel, with " I89" and its sodium salt, showed that these compounds possess very high curative properties in the trypanosomiasis of experimental animals.

In I922 Levaditi called attention to the desirability of being able to administer prophylaxis against syphilis by the oral ingestion of a treponemicidal drug in preference to local inunctions and intravenous injections. From soluble bismuth salts-lactates-no satisfactory results were obtained; so, in conjunction with Navarro-Martin, he commenced to investigate the arsenicals. It was decided that the addition of an acetyl group to "I89" would be of value in increasing the stability, reducing the toxicity, and thereby improving the $\mathrm{C} / \mathrm{T}$ ratio. Acetyl oxyaminophenyl arsinic acid and its sodium salt were therefore prepared :

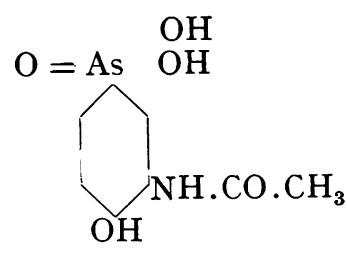

Acetyl oxyaminophenyl arsinic acid, "I90" or Stovarsol.
Sodium acetyl oxyaminophenyl arsenate or "Sodium Stovarsol." 


\section{BRITISH JOURNAL OF VENEREAL DISEASES}

It will be instructive to compare these formulæ with those already given of the other pentavalent compounds. Stovarsol is the pure acid, and is insoluble in water. The sodium salt was prepared because it was at first thought necessary, even by the oral route, for the compound to be given in solution. Sodium stovarsol is soluble in water, and as it gives a neutral reaction it is suitable for subcutaneous injection. Even if stovarsol were soluble in water, it could not be used for injection until it had been neutralised by, say, sodium hydroxide, just as is the case with salvarsan. The great point of this whole investigation was to find an efficient prophylactic against syphilis which acted through the digestive tract. There has already arisen à great deal of confusion with regard to stovarsol ; and in some of the English medical journals the impression has been given that this preparation is a sodium salt, whereas it is really the pure acid which is placed on the market under the name of "Stovarsol." It is unnecessary-perhaps it is even undesirable-for the compound to be in solution. The insoluble stovarsol is more conveniently administered, and has a greater effect by the digestive tract than has its soluble sodium salt given by any route whatsoever. It is this oral administration which gives stovarsol the place of prime importance in the prophylaxis of syphilis. Stovarsol has an arsenic content of $27 \cdot 2$ per cent. ; that of the sodium salt is $20 \cdot 3$ per cent.

Levaditi, Navarro-Martin, Fournier, Guenot, and Schwartz, in a paper entitled " Recherches sur l'action curative et préventive de l'acide acetyloxaminophenylarsinique, ' Igo ' ou Stovarsol administré par voie digestive dans la syphilis" (Annales de l'Institut Pasteur, xxxvi., 729, November, I922), describe the animal and human experiments upon which the claims of stovarsol are based. It is pointed out therein that while at the beginning the sodium salt was employed, it was later found that the pure acid was in every respect more valuable.

Animals having syphilitic lesions rich in treponemes were made to fast for twenty-four hours. They were then given by the mouth Io to 20 c.c. of a ro per cent. solution of sodium stovarsol. The progress of the lesions was noted, and daily examinations were made for treponemata. In the first experiment the rabbit received 2 grammes. The treponemata had disappeared by the 


\section{ARSENO-THERAPY OF SYPHILIS}

second day. A similar dose was then given, and by the fourth day the lesions had completely healed. The total dose was I.5 gramme per kilo body-weight.

Another rabbit was infected with two scrotal nodules, and, at the same time, it presented a chancre full of treponemata. One dose of 2 grammes was given. In twenty-four hours all the organisms had vanished, and the lesions were healed by the eighth day. The total dose was 0.66 gramme per kilo. Similar results were obtained in several other animals.

Two men, suffering from preputial chancres swarming with treponemata, were given "Igo" by the mouth. The first received a total dose of 16 grammes at the rate of from I to 2 grammes per day. Treponemata disappeared after I gramme had been taken. The second patient took I4 grammes at the same rate. The organisms had vanished after 7 grammes had been taken. In both cases the chancres rapidly became cicatrised. In the first patient a roseolar rash occurred during the treatment, but soon disappeared. A transient rise of temperature was also noted.

On February 3rd, I922, a man, aged twenty-five, volunteered to be inoculated on both arms with a dermotropic syphilitic virus. The same material was used at the same time to inoculate a monkey on the eyebrows. The man received, two and a half and sixteen hours after inoculation, 2 grammes orally -4 grammes in all. The monkey, on the tenth day, showed characteristic syphilitic lesions at the sites of scarification, and these progressed in a typical manner. The man, during an observation period of forty-seven days, showed no local lesion, and his W.R. remained negative.

These first experiments showed that " Igo " was a drug which, given by the mouth, prevented syphilis, and caused rapid healing of luetic lesions in man and animals. Levaditi pointed out, however, that the results were not sufficient to show that this mode of treatment leads to definite cure.

Further experiments on prophylaxis were then undertaken by Fournier, Levaditi, Navarro-Martin, and Schwartz, at the Pasteur Institute and at l'Hôpital Cochin. The animal experimental method was by the inoculation of the prepuce or scrotum with the neurotropic virus Pg., or the dermotropic strains of Truffi and 


\section{BRITISH JOURNAL OF VENEREAL DISEASES}

Fournier-Schwartz. The oral doses were given with the animals fasting for twenty-four hours. Untreated animals served as controls. In addition, the male rabbits infected with virus $\mathrm{Pg}$. were, after three or four dáys, mated with healthy females. The latter received, the next day, " I9o" by mouth.

At the Pasteur Institute there were three series of experiments with the virus Pg. :

(I) In the first series two animals received, the one 0.70 gramme per kilo, two hours after inoculation ; and the other I.4 grammes per kilo in two doses, two hours and twenty-four hours after inoculation. The control showed treponemata on the twenty-fourth day. The treated animals did not develop infection during the sixty days of observation.

(2) In the second series, one rabbit received $0 \cdot 16$ gramme per kilo after six hours ; and two others, $0 \cdot 33$ gramme per kilo after the same lapse of time. The control showed infection on the twentyeighth day, while the prophylactically treated animals remained uninfected.

(3) In the third series two rabbits received 0.25 gramme per kilo after five hours; three others got the same dose after twenty-three hours. Treponemata were demonstrated in the control on the twenty-second day. The treated animals remained healthy.

There were two series of experiments with the virus Truffi :

(I) In the first, two animals received $0 \cdot 18$ and 0.23 gramme per kilo after two hours. Two others were given 0.21 and 0.22 gramme per kilo after nineteen hours. In no case did disease develop during forty-three days of observation.

(2) In the second series, which consisted of three rabbits, each received $\mathrm{O} \cdot \mathrm{I}$ gramme per kilo twenty-four hours after inoculation. Disease did not result.

There were mated with males bearing active syphilitic lesions containing treponemata four female rabbits. These received by the mouth prophylactic doses of 0.5 , 


\section{ARSENO-THERAPY OF SYPHILIS}

I and 2 grammes per kilo. None contracted the disease during observation periods of thirty-five, forty-six, and sixty-four days respectively.

At l'Hôpital Cochin eight rabbits were infected by scrotal scarification with the virus Fournier-Schwartz. Of these, two received by the mouth, forty-eight hours after scarification, 0.25 gramme per kilo; and two received the same dose after seven days. The four treated animals remained free from infection, whereas three of the controls showed, after from four to six weeks, scrotal lesions rich in treponemata.

Human Experiments. - A man, aged thirty-two, who had never had syphilis and in whom the W.R. was negative, was inoculated on both arms with syphilitic material. A monkey was used as a control. The man, five hours afterwards, was given by the mouth 2 grammes, and no disease supervened during an observation period of sixty-eight days. His W.R. remained negative. The monkey showed treponemata on the eleventh day. This experiment was done in collaboration with $\mathbf{M}$. Marie. - Fournier and Schwartz had two interesting cases :

(I) Madame C., whose husband presented a syphilitic chancre of the penis of three weeks' duration in which treponemata were demonstrated, had recently had sexual connection with him. She showed no signs of syphilis and the W.R. was negative. She received in two series of three days 7 grammes at the rate of from $I$ to $I \cdot 5$ gramme per day. No disease occurred and the W.R. remained negative.

(2) Madame D. had had several recent sexual connections with her husband, who presented a syphilitic preputial chancre. She had no clinical signs and the W.R. was negative. She was given, by the mouth, 6 grammes in five days. Syphilis did not occur and the W.R. remained negative.

In all twenty-one animal experiments were done, and they showed that " I9o," given orally, five hours, six hours, twelve hours, twenty-four hours, two days and seven days after inoculation with treponemata, prevents syphilis occurring. The smallest dose used was $0 \cdot I$ gramme per kilo. The efficacy of the drug is equally 


\section{BRITISH JOURNAL OF VENEREAL DISEASES}

evident in rabbits exposed to the disease from sexual contact. The human experiments are confirmatory of these. They demonstrate that 2 grammes of " I90," given orally five hours after massive inoculation, prevents syphilis. In the two women where inoculation was by sexual connection, 6 to 7 grammes, given by the mouth and spread over five or six days, prevented the disease, which would otherwise most likely have resulted.

The doses were well tolerated; the only unusual occurrences being slight elevations of temperature and evanescent rashes. It was found, however, that in certain cases arseno-resistance was developed, and on this account it is necessary to maintain a certain reserve on the question of the constancy of the preventive and abortive power of this compound. Experience since then in the actual treatment of the established disease has shown that stovarsol has not a very marked effect upon the Wassermann reaction, although it compares favourably with the arsenobenzols in its power of rapidly healing superficial lesions.

There can be no doubt, however, that stovarsol, when given orally, promises to be a most efficient weapon for the prevention of syphilis, and must supersede all others. It should be given as a routine in every instance where there has been exposure to possible infection. If it bears out its promises, its value in the services, especially during war, will be incalculable.

The value of stovarsol might be assessed thus :

(I) It appears to be the most valuable prophylactic we possess at present which can be administered by the mouth.

(2) The relationship between its prophylactic dose and its toxic dose is a safe one.

(3) Its power of healing superficial lesions is at least equal to that of intravenous " 606. ."

(4) Its effect in curing established syphilis and of rendering a positive W.R. permanently negative is inferior to that of the arsenobenzols or bismuth, although it is superior to that of mercury.

The general position might be tabulated in the following fashion :

Stovarsól, prophylactic index $=$ Io ; curative index $=4$ Salvarsan,

$$
\text { , = 8; , , , = IO }
$$




\section{ARSENO-THERAPY OF SYPHILIS}

The value of stovarsol in the treatment of malaria, dysentery, and certain other tropical diseases is outside the scope of this review ; but it has been thought useful to include in the bibliography the more important references to the subject.

A recent arsenical which has attracted a considerable amount of attention is that known as Tryparsamide. This drug, which is the sodium salt of N-phenylglycineamide-p-arsonic acid, has the formula :

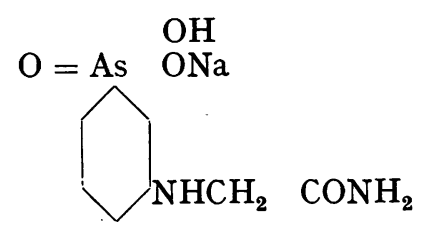

This was first prepared by Jacobs and Heidelberger, and the preliminary animal experiments were carried out by Brown and Pearce. The initial clinical investigations were undertaken by Loevenhart and Lorenz, by Pearce, by Smillie, and by Tyzzer.

Tryparsamide is a white, odourless crystalline powder, containing half a molecule of water of crystallisation. The dosage should not exceed 0.05 gramme per kilo of body weight, and should not be given oftener than once in seven days. The solutions should be freshly prepared with freshly distilled water. Needless to say, the strictest aseptic precautions must be observed. The solution is usually made by dissolving I to 3 grammes in Io c.c. of distilled water at room temperature. The solution must be perfectly clear, and in all cases should be filtered through sterile filter paper before injection. Turbidity of the solution contra-indicates its use. The injection is usually made intravenously, although it can be given by the intramuscular route.

The chief field for tryparsamide is in the treatment of trypanosomiasis; but it has a distinct value in certain cases of neurosyphilis. It appears to have a high power of penetration into the central nervous system. It is rapidly eliminated and cumulative effects are rare. Only the very early cases of neurosyphilis are suitable for treatment by this agent. It appears to be of no value in somatic lesions or in syphilis of the supporting structures of the central nervous system. In those with marked physical or mental degeneration the 


\section{BRITISH JOURNAL OF VENEREAL DISEASES}

administration of this drug may accelerate the progress of the disease. In patients who have shown an intolerance to arsenobenzol, one should be cautious with tryparsamide.

The great obstacle to the use of tryparsamide is the tendency for it to cause the occurrence of amblyopia. Every patient to whom it is proposed to administer this drug should have the fundi examined and the visual fields accurately measured by a competent ophthalmologist. Any abnormality of either of these is an absolute contraindication to the use of tryparsamide. During the course of treatment the fundi and the visual fields should be examined at fortnightly intervals, and on the appearance of any visual disturbance tryparsamide must be permanently discontinued.

\section{BIBLIOGRAPHY}

STOVARSOL.-References marked with an asterisk refer specially to syphilis; the others to tropical diseases, e.g., dysentery, malaria, trypanosomiasis, or to the chemistry of the compound.

Anglade. Centre méd., No. 7, I73, I924.

BaERmann. Arch.f. Sch. u. Trop. Hyg., 229, I923.

BEAL. Congrès Franç. de Stomatologie, Paris, I924.

*Bernard. Bruxelles méd., No. I8, 348, I924.

*Bernard et Thomas, Bull. de l'Acad. de Méd., No. 26, 800, I924.

Beurnier et Clapier. Rev. de méd. et de Hyg. Trop., No. 6, 240, I923.

*Beutl. Derm. Woch., 582, lxxx., I925.

Blanchard et Lefrou. Bull. de la Soc. de Path. Exot., No. 3, 2I4, I924.

*Bloch. Schw. med. woch., No. 36, 8I7, I924.

CADE et Ravault. Lyon méd., No. 29, 93, I924.

*Clement. Journ. des Pract., No. 35, 568, I924.

Coffart. Journ. des Pract., No. 24, 39I, I924.

Cot. Biol. méd., No. 7, 353, I924.

Couvy. Bull. de la Soc. de Path. Exot., No. 7, 530-555, I924.

*Cuichemarre. Le Gaz. méd. du Centre, No. I, 9; I923.

DECROP. Maroc méd., No. 32, 253, I924.

Delanoe. Maroc méd., No. I7, I50, I923.

Delanoe. Bull. de la Soc. de Path. Exot., No. 2, II8I, I924.

Dopter. Bull. de la Soc. de Path. Exot., No. 7, 553, I924.

*Duperie, Cadenaule et Clarac. Gaz. hebdo. des Sc. méd. de Bordeaux, No. 29, 456, I924.

*Favento. Il Policlinico, No. 36, II6o, I924.

*Fernet. L'Année méd. Pratique, 355, I923.

*Fiessinger. Journ. des Pract., No. 30, 493, I923.

Fontanel. Bull. méd., No. 24, 674, I924.

Fontanel. Maroc méd., No. 32, 248, I924.

Fontanel et Millischer. Lyon méd., No. io, 3I6, I924.

Fourneau. Ann. de l'Inst. Pasteur, September 9th, 57 I, I92I. 


\section{ARSENO-THERAPY OF SYPHILIS}

Fourneau. Paris méd., No. 5I, 50I, I923.

Fourneau, Navarro-Martin, et Trefouel. Ann. de l'Inst. Pasteur, No. 6, 55I, I923.

Fourneau et Navarro-Martin. C. R. de la Soc. de Biol., No. 37, II97, I922.

*Fournier, Levaditi, Navarro-Martin, et Schwartz. $C . R$. Acad. des Sc., No. 2I, I380, I922.

FulleborN. Klin. woch., No. 44, 2027, I924.

GaEHLINGER. Le Sud. méd. et chir., No. 2037, 2729, I924.

GaRIN. Lyon méd., No. 30, II7, I924.

*Gougerot. Le Journ. méd. Franç., No. 3, IIo, I923.

*GRunke. Die Therap. der Gegen., viii., 366, I924.

*Guillemot. La Presse méd., No. 43, 470, I924.

*Hasson. la Rev. méd. de l'Orient., No. 12, 4, I923.

*Heymann. Zentrablatt $f$. in. med., No. 28, 546, I924.

*Heymann. Med. klin., No. 42, October I9th, I924.

*Heymann. Faits du Méd., No. 20, December 3Ist, I924.

*Hoffmann. Dermat. ziet., Ior, October, I924.

*IDE. Rev. méd. de Louvain., No. 7, IOO, I924.

*JadAssohn. Klin. woch., No. 27, I221, I924.

*Jadassohn. Die Therap. der Gegen., No. 9, 4Io, I924.

*Kolle. Deut. med. woch., No. 32, I074, I924.

Leger. Bull. de la Soc. de Path. Exot., No. 9, 635, 1923.

*Lehner u. Radnal. Med. klin., No. 9, I925.

*Levaditi. Conférence ft. à l'Inst. Pasteur sur la prophylaxie de la syphilis, April, I923.

*Levaditi. Bruxelles méd., No. 27, Ior3, r923.

*Levaditi et Navarro-Martin. C. R. Acad. des Sc., No. I3, 893, I922.

*Levaditi, Navarro-Martin, Fournier, Guenot et Schwartz. Ann. de l'Inst. Pasteur, No. II, 729, I923.

*Levy-Bing et Ferond. Ann. des mal. vener., No. 3, 97, I923.

*Luerssen. Klin. woch., 699, iv., I925.

Marchoux. Bull. de la Soc. Path. Exot., No. 2, 79, I923.

Marchoux. Biol. méd., No. 4, I78, I923.

Marchoux. Bull. de la Soc. Path. Exot., 235, May, I923.

* Mazza. La Prenza méd. Argentina, No. 35, Ior3, I923.

NavarRo-Martin et Stephanopoulo. Soc. de Biol., No. I3, 702, I922.

*Nicolau. Paris méd., No. 2I, 467, I923.

Nogue et Leger. Bull. de la Soc. Path. Exot., No. 7, 557, I923.

*Oppenheim. Wien. klin. woch., No. I2, 29I, I924.

*OpPENHEIM. Wien. klin. woch., No. I7, 422, I924.

*Oppenheim. Med. klin., No. 36, I240, I924.

*Oppenheim. Ziet. f. angew Chemic., No. 4I, 820, I924.

Oretschins. Praktit. Wratch., September-October, I924.

Petzerakis. La Presse méd., No. 69, 709, I924.

Peyrot. Marseille méd., No. 21, 932, I924.

*Pierret. Biol. méd., No. 3, 125, 1923.

*Pinkus. Med. klin., No. 22, 739, I924.

Plehnu u. Mense. Hb. a. Tropenkrankheiten, Leipzig, r924.

*Pomaret. Ann. des mal. vener., October, I923.

*Rathery. Paris méd., No. 48, 488, I922.

Rubenthaller et Jansion. Paris méd., No. 23, 538, i924.

v.D.

335

c c 


\section{BRITISH JOURNAL OF VENEREAL DISEASES}

SAAD. Biol. méd., No. 7, 360, I924.

Sabrazes. Gaz. hebdo. des Sc. méd. de Bordeaux, No. 3I, 482, I924.

*SChumacher. Dermat. woch., Nos. 38 and 39, III7 and II5I, I924;

Deut. med. woch., II96, July I7th, I925.

*Sezany. La Prat. méd. Franç., No. II, 487, I924.

*Sezany et Pomaret. Bull. et Mem. de la Soc. méd. des Hôp. de

Paris, No. 7, 318, I923, and April 2oth, 595, I923.

*SPIETHOFF. Med. klin., 20I, xxi., I925.

Tanon et Jamot. Rev. de méd. et de hyg. trop., No. I, I8, I924.

*Tixier. La Presse méd., No. 83, 818, I924.

*V_. Journ. de méd. de Bordeaux, No. 20, 827, I923.

Valenti e Tomaselli. Il Policlinico, No. 36, II59, I924.

*Viadel. Sc. méd., 332, October 3Ist, I922.

WALdORP. La Semana méd., No. I8, 787, I924.

*Weitgasser. Med. klin., No. 28, 966, I924.

*Weitgasser. Med. klin., No. 42, I469, I924.

*WolfF. Nederland. Tijdschrift voor Geneeskunde, No. 20, 2053, I923.

*WoRms. Exper. untersuchungen mit. Stovarsol. Dtsch. vereing $g . f$. mikrobiol. i. Gottingen., I924.

*Worms. Deut. med. woch., 428, li., I923.

*X- Le méd. Franç., 44, October Ist, I922.

*Yovanovitch. Thèse Paris, I924.

\section{Authorities Quoted in Text.}

Bechamp. C. R. de l'Acad. des Sc., lvi., II72, I863.

Benz u. Schulz. Arch. f. exper. Path. u. Pharm., ii., 200, 1879.

EHRLICH. Ber. d. Deut. chem. Gesell., xl., 3292, I907.

EHRLICH. Ber. d. Deut. chem. Gesell., xli., 93I, I672, I908.

Ehrlich. Ber.d. Deut. Chem. Gesell., xliii., 924, I9Io.

EHRLICH. Die. exp. chemother. der Spirill., I9Io.

EHRLICH. . Handbuch. der Path. mikro-organ., I9I3.

HerzFeld. Journ. Amer. Med. Assn., lvi., 588, I9II.

MOORE. Brit. Med.J., i., 6I7, I9I6.

Morgan. Organic Compounds of Arsenic and Antimony, I9I8.

MULzer. Chemotherapy of Syphilis.

Puckner and Hilpert. Journ. Amer. Med. Assn., lv., 2134, IgIo.

RoHL u. FRIEDBERGER. Ziet. Imun. f. u. exper. ther., i., I909.

ROHL u. FRIEDBERGER. Ber. klin. woch., 38, I908.

ROHL u. FrIEDBERGER. Ber. klin. woch., II, I909.

ROHL u. FrIEDberger. Therap. Monats., May, IgII.

Sieburg. Ziet. Phys. chem., xcvii., 53, I9I6.

TRYPARSAMIDE.

(I) Chemical Papers.

Jacobs, W. A., and Heidelberger, Michael. J. Amer. Chem. Soc., xli., I587, I9I9.

Jacobs, W. A., and Heidelberger, Michael. J. Exp. Med., xxx., 4II, I9I9.

(2) Biological Papers.

Brown and Pearce. J. Exp. Med., xxx., 4I7, 437, 455, 483, I9I9.

Brown and PeArCe. J. Exp: Med., xxxiii., I93, I92I. 


\section{ARSENO-THERAPY OF SYPHILIS}

Tyzzer, E. E. J. Exp. Med., xxxvii., 85I, I923.

Voegtlin, Smith, Dyer and Thompson. Public Health Report, May IIth, No. 835, I003, I923.

Mehrtens, Kolos and Marshall. Arch. Neur. and Psych., xii., 67, I924.

Young and Muehlberger. J. Pharm. and Exper. Thera., xxiii., 46r, I924.

Fordyce, Rosen and Myers. Am. J. Syph., viii., 264, I924.

FORDYCE, ROSEN and MYers. Am. J. Syph., viii., 377, I924.

Young and Loevenhart. J. Pharm. and Exper. Thera., xxiii., I07, I924.

\section{TRYPANOSOMIASIS.}

Pearce. J. Exp. Med., xxxiv., No. 6, Supplement No. I, I92I. Lefrou and OuzIlleau. Bull. Soc. path. exot., xv., 802, I922.

Chesterman. Trans. Roy. Soc. Trop. Med. and Hyg., January, xvi., No. 7, 394, I923.

VAN DEN BRANDEN and VAN Hoof. Bull. Soc. path. exot., xvi., 606, I923.

Morgan. Am.J.Med. Sci., clxvii., 827, I924.

Smillie. J. Am. Vet. Med. Assoc., September, I923.

Chesterman. Trans. Roy. Soc. Trop. Med. and Hyg., vol. xviii., No. 3, June, I924.

Letonturier, De Margueissac et Jamot. Bull. Soc. path. exot., xvii., 692, I924.

\section{NEUROSYPHILIS.}

LOREnZ. Wis. Med. J., xx., 336, I922.

Lorenz, Loevenhart, BleckWenn, and Hodges. J.A.M.A., Ixxx., I497, I923.

Moore, Robinson and Keidel. J.A.M.A., lxxxii., 528, I924.

WoOds and MoORE. J.A.M.A., lxxxii., 2105, I924.

Solomon. J. Ner. Ment. Dis., lix., 299, I924.

VIner. Canadian Med. Assoc. J., xiv., 7I9, I924.

Hindman. Ohio State Med. J., August, I924.

Ebaugh. J.A.M.A., lxxxiii., 803, I924.

LILLIE. J.A.M.A., lxxxiii., 809, I924.

Moore, Robinson and Lyman. J.A.M.A., Ixxxiii., 888, I924.

Solomon and VIETS. J.A.M.A., lxxxiii., 89I, I924.

Lorenz, Loevenhart, Reitz, and Eck. Am. J. Med. Sci., clxviii., I57, I924.

Guillain and Girot. Bull. Acad. Méd., xcii., 850, I924.

Claude and Targowla. Comp. rend. Soc. Biol., xci., 527, r924.

Stokes and Wilhelm. Arch. Dermat. and Syphil., x. (in press), I924.

Wile and Wieder. J.A.M.A., December 6th, lxxxiii., I824, I924.

Bluemel and Greig. Colorado Med., January, I925.

Crawford. Canadian Med. Assoc. Jnl., 46, xv., January, I925.

\section{Comments And Reviews.}

Brown and Pearce. J.A.M.A., lxxxii., 5, I924.

PeArce and Brown. N.Y. State J. Med., xxiv., No. I6, I924. 


\section{BRITISH JOURNAL OF VENEREAL DISEASES}

Cheinisse. Presse Méd., xxxi., 8I, I923.

MotT. Brit. Med. J., ii., 24, I923.

Hanschell. Brit. Med. J., I923, ii., 87, I923.

EDITORIAL. "Tryparsamide in the Treatment of Syphilis," Brit. Med.J., i., 537, I924.

Cheinisse. Presse Méd., xxxii., 303, I924.

LEY. J.A.M.A., lxxxiii., 702, I924.

Viner. Canadian Med. Assoc. J., xiv., 978, I924.

Cheinisse. Presse Méd., xxxii., 886, I924. 